\title{
Relative Clauses in Minangkabau, Indonesian, English Languages (Typology Study)
}

DOI: https://doi.org/10.47175/rielsj.v2i2.235

\author{
| Akmal $^{1}$ | Mulyadi ${ }^{2}$ | \\ 1,2 Linguistics Science, \\ Universitas Sumatera Utara, \\ Medan, Indonesia

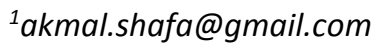 \\ ${ }^{2}$ mulyadi@usu.ac.id
}

\begin{abstract}
Minangkabau and Indonesian languages are an Austronesian. In this study, it was focused on the typology study of three different languages, namely: Minangkabau, Indonesian, and English relative clauses. It aimed to find out the differences and the similarities of relative clauses among the three languages. This paper also outlines the Accessibility Hierarchy approach to the facts that describe building on relative clause construction. The data was taken from some conversations with Minangkabaunese friends and feedback from the writer as a native speaker of the language in the analysis as well as taking the findings of recent typological and theoretical studies of Austronesian languages into consideration. From the analysis, it is found that Minangkabau and Indonesian languages are same contsruction and the english is different between Minangkabau and Indonesian languages. In the English, it is also possible to have object focus which called object fronting.

KEYWORDS

Relative Clauses; Typology; construction
\end{abstract}

\section{INTRODUCTION}

Language is an autonomous cognitive ability or a separate module with nonverbal cognitive abilities (Hoang, 2020). In the linguistics, the typology was the classification of the world's languages to find out the sameness and the differences in the structures. Then Mallinson and B.J. Blake (1981:264) in Ambarita, R and Mulyadi stated that in the traditional English books, the clauses are relatively the same as adjunctival clauses, for that reason relative clauses are related to qualifiers or modifiers of constituents consisting of nouns (Ambarita $\&$ Mulyadi, 2020). In the real fact, many ethnics languages almost endangered in many areas when they communicate each other in their community. So as the Indonesian citizen, the ethnic needs to save by doing the research the languages in Indonesia especially.

According to Kroeger that a clause is sometimes called as a simple sentence. So a clause is the smallest grammatical unit which was able to express a complete proposition (Kroeger, 2005). Then in this case, there are some clauses which are found in forming a sentence, one of them is the relative clause. The relative clause is a clause which can modify and explain a noun phrase, besides that it functions to show something which is determined to the noun phrase (Jufrizal et al., 2009; Utami et al., 2013). It means that a clause is the smallest element of grammar which is used to form a sentence. So one clause is one sentence and more than the clauses can be a sentence. It means that in one sentence, it can be one clause and it can be more than one clause. One sentence consists more than one clause and it includes in the relative clause. According to Kridalaksana (1993:110) stated that a clause is a group of words in the grammar unit which consists of at least subject and predicate and it has a potence to be a sentence. Both experts' opinions are supported each other in giving the definition of the clause so clearly so that it is easy to understand many people especially the students. Then a 
sentence is mainly a group of words linking together and expressing an idea, event or description. The boundaries of a sentence are easily identified that a sentence is begun a capital letters and ended by full-stop (Indrawati, 2017).

A relative clause (it is shortened ' $r c$ ') is a subordinate clause which delimits the reference of the noun phrase (it is shortened $n p$ ) by specifying the role of the referent of that noun phrase in the situation described by the relative clause (rc) (Andrews, 2007). From two different definitions, the relative clauses have at least two clauses namely one main clause and subordinate clause which are related to the relative words (Ariyati et al., 2020; Jufrizal et al., 2009; Utami et al., 2013).

So relative clause is a clause which consists of the dependent and subordinate clause that in the transformational grammar, especially in the generative structure, commonly called an embedded clause because a clause attached or pinned on one of higher constructional elements. A sentence or a clause pinned the position of subordinate clause was called the matrix clause, the independent clause, or a main clause (Ambarita \& Mulyadi, 2019). Furthermore, the English Relative Clauses with the formal type is based on (1) the use of special pronouns, it is called relative pronouns who, which, whom, what, where, and when, (2) the subordinator that, and (3) the use of a 'gap' or empty structure which means that there are the missing constituents in a relative clause structure (Utami et al., 2013).

The relative clause (or RC hereafter) - with the beginning of word order and the case marking - took a very prominent positon in the linguistic typology. Keenan and Comrie's (1977) cross-linguistic study, which deals with none other than grammatical constraints on relativization or relative clause formation, is regarded as 'one of the most influential works in the language universals literature'. The relative clause construction, as is generally understood, it belongs to two components, they are the head noun and the restricting clause. The semantic function of the head noun is to make a set of entities, which were able to be called the domain of relativization, as Keenan and Comrie (1977: 63) explained that, whereas that the limitation of the clause is to make the identification of a domain subset - a onemember subset in the case of (1) below - by pressing the conditional semantic on the domain of the relativization referred to the head noun, the role of the head noun is expressed in the restricting clause. Then There are three main ways of dealing with the head of the relative clauses: 1). Obliteration / gapping: the head is not elaborated at all of the clause, it can be seen this clause, the boy (whom) they met. In the relative clause the non-expressing head is in object function and it is called a subordinator. 2). Relative pronouns (it is shortened rp): these relative pronouns (rps) gave the indication that the clause is a relative clause ( $\mathrm{rc}$ ) and in addition provide information about the syntactical function of the head of the $\mathrm{r} c$, as example: the girl whose bag I bought. The whose word indicated that the head is a possessive word. 3). Pronoun retention ( $\boldsymbol{p} \boldsymbol{r})$ : it is often in combination with a subordinator as example :the girl that I got this bag from her (Rosita, 2015).

Indonesian is a national language in Indonesia which functions as national communication when the people of other ethnics communicate each other because there are so many ethnics languages in Indonesia and one of them is the Minangkabau language. The Minangkabau language and other languages have the same role and position in Indonesia because the languages have been protected by UUD 1945. Minangkabau language also has the structural rules and roles in using by the society in the West Sumatera area (Ariyati et al., 2020; Jufrizal et al., 2009, 2015; Lindawati, 2015; Rasyad et al., 1986).

Then in commonly, the relative clauses in Indonesian language refer to the rules of English or other western languages, so that their rules or roles have similarites which are sometimes interesting phenomena. For example, in English, there are at least 3 main features of the Relative Clause, namely (1) it has to be an antecedent (Ant), the noun phrase of the 
core clause must be the same as the nominal phrase relative clause; (2) it has to be a relator / assembler of the core clause with the element of the Relative Clause ( $\mathrm{rc}$ ) positioned before the Relative Clause; and (3) the relator has to take the position one of the syntactical functions in the Relative Clause (Ambarita \& Mulyadi, 2020). Alotaibi (2016: 58) in Sari and friends stated that relative clauses are marked with a yang relative word. This type of clause functions to change the noun attached as the main clause (Sari et al., 2017).

Then Rosita (2015) stated that The basic word order in the clause consists of a Subject, Verb, and Object (SVO), with the head previous modifier in the phrase. While the lexicon and the phonology of this language is really same to Standard Indonesian. Relative clause ( $\mathrm{r}$ c) is as an adding information about a noun is by incorporating a clause within the noun phrase. This clause is signed by "nan" word in the Minangkabau language. The head of the noun phrase corresponds to some components within the relative clause (Rosita, 2015).

The researcher was interested in this study because the typology was focused on the comparative of languages in the same topics of structure. The problems of this study: what are embedded relative clauses in Minangkabau, Indonesian, and English languages? How are the embedded relative clauses in three different languages?

\section{RESEARCH METHODS}

In this study, the researcher used the qualitative research design by using the documentary library and comparative analysis of the study. the qualitative research focuses on gathering and interpretation of non-numerical data (elaboration/description). It is also to describe and explain more details the differences of Minangkabau, Indonesian, and the English language in the syntax phenomenon (Adedoyin, 2020). The qualitative research was to get the insights into these constructions of the reality, i.e., to tease out the nature of the world as it was experienced, structured and interpreted by the people in the course of their everyday lived. The information of qualitative, the researcher collected the data to get the necessary thing was largely, although not always, obtained by the means of the descriptives in which the people being studied to communicate the way they understood the world (Cropley, 2019).

In this study, the researcher took the data from the documantary library. The dokumens which were taken from the books, teaching module, and the scientific article or papers about the relative clauses in Minangkabau language, the Indonesian language, and the English language as the data of this research. The sources of documents were also taken from the internet because the situation was impossible to get the books manually. Besides that, the reseacrher also asked the informan of Minangkabau people who really understand about the relative clause topic.

In getting the data, the researcher has done as following below: a). The researcher opened the internet and searched on the website of Minangkabau language and Indonesian study. b). After that the researcher searched about the relative clauses in Minangkabau language, Indonesian, and English languages. c). After all the books or article were opened, the researcher had to choose the documents which were really related to the structure of relative clauses in three different languages. d). The last, the researcher had to compare to see what relative clauses word was in the Minangkabau, the Indonesian, and the English languages.

\section{RESULTS AND DISCUSSION}

The relative clauses are a word "nan" in the Minangkabau language, a word yang in the Indonesian language, and some words such as who, which, whom, and whose in the English language. It can be seen the relative clauses in the Minangkabau language, the Indonesian language, and English language in the table 1. 
Table 1. Relative clauses structure

\begin{tabular}{|c|c|c|l|}
\hline Languages & Minangkabau & \multicolumn{1}{|c|}{ Indonesian } & \multicolumn{1}{|c|}{ English } \\
\hline Relative Clauses & nan & Yang & $\begin{array}{l}\text { who, which, whom, } \\
\text { whose, where, when. }\end{array}$ \\
\hline
\end{tabular}

Relative clauses are often called adjective clause because the functions of clauses are as a noun and the main clause. English relative clause have a complex structure by some relativized kinds. Relative clauses in English are classified into two types: formal and relational. As Huddleston (2002:1033) stated, formal RC is marked by the use of: (1) relative pronouns who, which, whom, whose, where, when, and another wh questions; (2) subordinator that; and (3) gap structure. Those relativizers can be used in the position of relativizing (1) subject, (2) object, (3) object of preposition, (4) possessive, and (5) adverb. These are examples of such positions (Novianto \& Suhandano, 2019).

\section{The relative clauses were focused on the subject, the object, the gap of preposition,} the possessive.

It is as A Subject

1. Minangkabau :Urang tu duduak

Indonesian : Orang itu duduk

$3^{\text {rd }}$ det verb

English : Person that is sitting

That person is sitting

2. Minangkabau : Urang tu bakarajo jo ambo

Indonesian : Orang itu bekerja dengan saya $3^{\text {rd }}$ det predicate prep.

English : Person that works with me That person works with me

3. Minangkabau : Urang tu nan duduak, bakarajo jo ambo Indonesian : Orang itu yang duduk, bekerja dengan saya $3^{r d}$ (singular) rel verb(sitting), verb(work) prep. The object

English : The person (who) is sitting, works with me.

The clause in (1), it is able to be embedded within the N P subject of the clause in example number 2 (two) and it can be the clauses of the examples number 3 (three). The relative clause is derived from the clause in examples number 1 (one) by step (i), (ii) and (iii) above and occurs as a subject of clause in the examles number 3 (three). The subject of the example number 3 (three) ends with the optional ' $t u$ '. Although ' $t u$ ' identifies the subject of the clause in the examples number two (2), this is also achieved by the relative clause. In the clause in (3), it is called embedded clause in the pre-nominal. In this case 'tu' is more likely to be omitted from the embedding phrase. In Minangkabau 'nan' must occur before a relative clause although in English corresponding 'who' or 'which' can be sometimes omitted.

4. Minangkabau : gadih nan ambo berikan buku, rancak

Indonesia : gadis yang saya berikan buku, cantik

Girl who-Dative I gave book, pretty.

English : girl to whom I gave the book, is pretty

The girl whom I gave the book, is pretty

5. Minangkabau : Sarawa nan dibali padusi tu ketek bana.

Indonesian : Celana yang dibeli gadis itu, kecil sangat

Plural rel di-verb the girl, det. Adj.

English : Troausers (that were) bought the girl, were small very. 

6. Minangkabau : Oto
Indonesian nan dilantak bis koto tu rusak.
English
: Mobil yang ditabrak bis kota itu, rusak
: The car (which was) hit the city bus, is broken.

The trousers (that were) bought the girl, were very small

In the case of clause in (4), the relative - dative where the relative pronoun who functions as object so the relative changed to be whom.

\section{As an object}

The relative clause was able to consist of any constituents which occured in an independent clause except the subject, which was to identify to the head of the embedding noun phrase. Since the head noun really stood in the same connection to the verb as the subject of the clause that connection of clause had to be shown by the verb. The relative clauses of the object pattern type in the English did not change the voice of the verb especially in the Minangkabau language did. That was, the antecedent referred to by the relative pronoun can be an object that focused on the Minangkabau language, the Indonesian language, and the English language. Compare the following Minangkabau, Indonesian, English languages. It can be seen the examples as follows:

7. Minangkabau: Urang tuo nan Rina tamui di sekolah tu adolah kakeknyo Indonesian : Orang tua yang Rina temui di sekolah itu adalah kakeknya English : The old man (whom) Rina met at the school, is grandfather (her) : The old man (whom) Rina met at the school, is her grandfather

8. Minangkabau : Para Demonstran nan ambo tonton di TV tu manakuikan. Indonesian : Para Demonstran itu yang saya tonton di TV itu, menakutkan. English : Demonstrans whom I watched on TV, was scary The demonstrans whom I watched on TV, was scary

The both statements of relative clauses are so often either in speakings or in writings which are talked to the speakers in the society. Sometimes the Minangkabau and Indonesian languages are not same to the English language in translate because of the structure in the languages. Kadarisman (2002:3) also gave the explanation that it is the carrying over of a syntactic structure in English into Indonesian and also Minnagkabau. Then the clauses in (7) and (8), they can be pre-nominal because the relative pronoun of whom can be omitted and the pronoun-retentions are occurred in the clauses where as the relative who change to be whom.

The object-focus on the construction in Minangkabau that were different from cleft in the English, e.g "That is the girl that we have met", or "That is the car, we are looking for". In Minangkabau, the cleft sentences were equal to object-focus + lah construction, e.g "gadih tulah nan pernah kami tamui", dan "Oto tulah nan sedang kami cari" cleft sentences are equal to object-focus + -lah construction, e.g Gadis itulah yang pernah kami temui, and Mobil itulah yang sedang kami cari".

The rule that the verb has to be passive, follows a noun which stands as object to it is able to cause difficulty for English speaker as in English the verb is able to be and usually active in this context.

9. Minangkabau : Rumah nan dibuek ajo Madi, gadang

Indonesian : Rumah yang dibuat bang Madi, besar

DO rel di-build brother Madi, big

English : House which built brother Madi, is big

The house which was built brother Madi, is big.

10. Minangkabau : angkot nan amak naiki indak baranti di Kuraitaji.

Indonesian : angkot yang ibu naiki tidak berhenti di Kuraitaji. 
DO rel $1^{\text {st }} \quad$ took-i, didn't stop in Kuraitaji.

English : City bus which mother took, didn't stop in Kuraitaji.

The city bus which mother took, didn't stop in Kuraitaji

Here in English we can see that subject relative formulates in active but in Minangkabau and Indonesia it should be in passive or bare passive prefixless. Minangkabau and Indonesia languages are same forms.

\section{Verbal suffixes}

The verbal suffixes did not change in the relative clauses. Thus the head of noun was able to have any participant roles that the subject of an independent passive clause belongs. In the first example below the head noun stood as the recipient and in the second it was as the beneficiary.

11. Minangkabau : Saketek urang nan bakirimi surek alun manjawek

Indonesian : Sedikit orang yang dikirimi surat belum menjawab

A few 3rd rel ba-send-i DO have yet not answered

English $\quad:$ a few $3^{\text {rd }} \quad$ who were sent letter, have yet not answered

A few persons who were sent a letter, have not replied it yet.

12. Minangkabau : Urang mudo nan bacarian karajo sangek basyukuar

Indonesian : Orang muda yang mencari kerja, sangat bersyukur

3rd rel ba-search-an DO, is very grateful

English : man young who was searching work, is very grateful.

The young man who was searching the work, is very grateful.

The relativizatized subject was more than the object or low position by fact that Minangkabau and Indonesian languages possess a system of verbal inflection which allows patient to appear in subject position with a change on the verbal voice.

13. Minangkabau: Piliahlah padusi baiak nan ala waang tau bana

Indonesian : Pilihalah perempuan baik yang telah kamu kenal benar

Choose-lah IO rel has 2nd know

English : Choose good girl whom have you know very well

Choose a good girl whom you have known very well

Keenan and Comrie (2004) stated that Minangkabau and Indonesian have the primary strategies that apply only to subject on the assumption that 'focus' NP is the subject just like others Western Malayu-Polinesian language, Bataknese language as an example which was used in North Sumatera provinces and Indonesia country. It is postnominal and-case. They gave the examples on Bataknese language, but if we analyze it further by giving Minangkabau and Indonesian sentences, they will share common the universal feature of relative clause sentence.

14. Minagkabau: Mancuci sawawah padusi tu

Indonesian : Mencuci kain perempuan itu

Man-wash DO $\quad 3^{\text {rd }}$ det

English : Washes cloth woman that

That woman is washing the cloth

15. Minangkabau: Padusi nan mancuci sarawah tu

Indonesian : Perempuan yang mencuci kain itu.

3rd rel man-wash DO the

English : woman who is washing cloth that

The woman who is washing that cloth 


\section{Oblique}

It was usually identical to the noun phrase in a prepositional phrase, one indicating location. The noun which followed the preposition, is deleted and replaced by -nyo. The following basic clause contained a prepositional phrase as an adjunct of location:

16. Minangkabau: Di sampiang kadai tu, ado pohon anggur. Indonesia : Di sampiang kedai itu, ada pohon anggur.

$$
\text { Prep. Det }
$$

English : Beside shop that, there is a tree grape.

Beside that shop, there is a grape tree.

This could be embedded in a noun phrase whose head was kadai 'shop'. kadai tu was deleted from the prepositional phrase and its place were taken by -nyo:

17. Minangkabau: Kadai nan di sampiangnyo ado pohon anggur

Indonesia : Kedai yang di sampingnya ada pohon anggur

English : Shop which beside it, there is a tree grape.

The shop which is beside, there is a grape tree.

In such constructions the preposition occurs at the beginning of the relative clause, immediately after ' $n a n$ '. The preposition involved is usually a locative preposition, as in the first example below. In the other examples below it is the recipient preposition untuak ' $t o$ ' and the benefactive preposition untuk 'for':

18. Minangkabau: urang nan untuaknyo ambo mangiriman surat

Indonesia : Orang yang untuknya saya mengirimkan surat

English : Person for him I send a letter to

The person I send a letter to

19. Minangkabau : Anak nan untuaknyo ambo mambali kado

Indonesian : Anak yang untuknya saya belikan kado

English : Child for him I bought gift

The child I bought the gift for

\section{Genetive}

The topic of the topic-comment clause is deleted; the noun of the embedding phrase then stands as topic (not subject) to the relative clause. The -nyo (in Minangkabau language) nya (in Indonesian language) of the relative clause identified the head of the noun phrase. 'whose' in the possessive of topic-comment relative clauses, which translate constructions with 'whose' in English, the subject of the relative clause is the thing possessed by the head noun. The first example below derives from the independent clause.

20. Minangkabau: Kudo tu namanyo Tegap, bajalan dengan tanang bana Indonesia : Kuda itu yang namanya Tegap, berjalan dengan tenang benar.

English : Horse that whose name is Tegap, walked calmly really. That horse whose name is Tegap, walked really calmly

\section{Locative Relative Clauses}

These differ from other relative clauses in that they are not preceded by 'nan'. The more traditional construction begins with 'tempat', translated 'where'

21. Minangkabau: Perusahaan dima mereka bakarajo jauah dari siko Indonesia : Perusahaan dimana mereka bekerja, jauh dari sini.

English : The company where they worked, is far from here.

The sentence above is so familiar in the spoken of Minangkabau people especially in the middle of society because the word of dima is easier to speak than they speak" perusahaan tampek mereka bakarajo jauah dari siko". 


\section{CONCLUSION}

This paper has provided first description of Minangkabau language and Indonesian that relative clause formations in this language show a peculiar characteristic. It is can be concluded that in the Minangkabau language, only subject can be relativized and object can't. Since object can't be relativized, automatically the lower level in the Accessibility Hierarchy can't also be relativized. That is, although object relatives are grammatical, they are very rarely produced by speakers of Minangkabaunese and it will be awkward to be produced; instead speakers of Minangkababu produce subject relatives in which the subjects of passive sentences get relativized. I argued that the ease of passivization in Minangkabau makes it possible for indirect relativation of objects to be realized as subject relatives. Speakers of Indonesia generally, and Minangkabaunese especially, prefer this type of relativization because of its less processing cost than direct relativization

The relative clauses in Minangkabau, Indonesian, and English languages is one of topics in typology study. The researchers hope that there are other researchers who analyze any topics in typology especially in three different languages so that the study can be studied many students who are studying linguistics.

\section{REFERENCES}

Adedoyin, O. B. (2020). Qualitative Research Methods. Principles of Social Psychiatry: Second Edition, 77-87. https://doi.org/10.1002/9780470684214.ch7

Ambarita, R., \& Mulyadi. (2019). Relative Clause of Indonesian and Java Language. Scholar International Journal of Linguistics and Literature, 8677, 85-89. https://doi.org/10.21276/ sijll.2019.2.5.1

Ambarita, R., \& Mulyadi. (2020). Indonesian Relative Clauses And Its Similarities. PROJECT (Professional Journal of English Education), 3(6), 111-112.

Andrews, A. D. (2007). Language Typology and Syntactic Description. 2 dn Edition. Volume II: Complex Constructions (T. Shopen (ed.); Second Edi, Vol. 2). Cambridge University Press. http://marefateadyan.nashriyat.ir/node/150

Ariyati, R. P., Yusdi, M., \& Lindawati. (2020). Kalimat dan Klausa pada Novel "Lubang dari Separuh Langit. Jurnal Um-Tapsel, 5(1), 179-186. https://doi.org/10.31604/ linguistik.v5i1.179-186

Comrie, B. (1989). Language Universals and Linguistic Typology: Syntax and Morphology. second edition. University of Chicago Press.

Cropley, A. (2019). Introduction to qualitative research methods. In A research handbook for patient and public involvement researchers. https://doi.org/10.7765/9781526136527.00012

Ekaristianto, F. B. H., Purnanto, D., \& Sumarlam. (2019). Klausa Relatif Bahasa Indonesia : Sebuah Pendekatan Tipologi Sintaksis. Prosiding Seminar Nasional Linguistik Dan Sastra (SEMANTIKS), 1-3.

Hoang, P. N. (2020). Teaching Language in Cross-Disciplinary Contexts. Randwick International of Education and Linguistics Science Journal, 1(1), 36-43. https://doi.org/10.47175/rielsj.v1i1.27

Indrawati, N. L. K. M. (2017). Complementiser and Relativiser in the English Subordinate Clauses. Lingual, 8(1), 1-9.

Jufrizal, Rusdi, \& Refnita, L. (2009). Struktur Informasi pada Klausa Bahasa Minangkabau. Lingua Didaktika, 2(4), 58-69.

Jufrizal, Zaim, M., \& Ardi, H. (2015). Struktur Gramatikal dan Budaya Berbahasa : Data dan Informasi Bahasa Minangkabau.

Kroeger, P. R. (2005). Analyzing Grammar An Introduction. In Journal of Chemical 
Information and Modeling (First Edit, Vol. 53, Issue 9). Cambridge University Press. https://doi.org/ 9780521816229

Lindawati. (2015). Bahasa Minangkabau. Minangkabau Press. minangkabau_press@yahoo.com

Novianto, W., \& Suhandano. (2019). Production of Relative Clauses by English Learners. 3rd English Language and Literarture International Conference (ELLiC), 3(February), $50-56$.

Rasyad, H., Said, C., Busri, Amir, Z., Yamin, M., \& Gani, R. (1986). Frase Bahasa Minangkabau. Pusat Pembinaan dan Pengembangan Bahasa Departemen Pendidikan dan Kebudayaan.

Rosita, N. (2015). Relative Clause Formation in Minangkabau Language: An Accessiblity Hierarchy Motives. Africa's Potential for the Ecological Intensification of Agriculture, 3(9), 1689-1699.

Sari, A. M., Andayani, \& Sumarlam. (2017). Penggunaan Klausa Relatif pada Pembelajar Bipa di Unit Pelaksana Teknis (Upt ) Bahasa Universitas. Diglossia, 9(1), 45-64.

Utami, N. P. C. P., Artawa, K., \& Indrawati, N. L. K. M. (2013). Struktur dan peran nomina inti klausa relatif bahasa inggris. 34 . 